\title{
Impact Of Emotional Intelligence Training Programme On Social Adjustment Of Secondary School Students
}

\author{
Nimisha Beri, Anoop Beri
}

\begin{abstract}
In the modern time change in different aspect of life like school, home and workplace had been linked with emotional intelligence. Emotional intelligence shows one's ability to live their life and to adjust in different environment. Emotional intelligence is very much essential to deal with the new environment and one's own feelings. If the people are emotionally intelligent then they can get success in their life, and it helps the person in every field of life. If people have better understanding of the relationship then they can easily complete their task and can get achievement in the life.
\end{abstract}

\section{INTRODUCTION}

Emotions play a very important role in our life. It is essential to know how they affect individual and social adjustments (Punia and Sangwan, 2011). It is evident that emotions are involved in day to day work lives (Stubbs, 2005). Emotional intelligence is becoming more widely known, and the definitions of each aspect of the different skills that make up emotional intelligence need defining (Veitch and Justice, 2011). Ulutas and Omeroglu (2007). Zia et al., (2014) found that training emotional intelligence significantly affected the enhancement of organizational maturity and reduction of job burnout. However, training emotional intelligence enhanced organizational maturity and reduced job burnout.

\section{EMOTIONAL INTELLIGENCE}

Emotional intelligence is a skill to recognize, employ as well as control feelings in good manners to decrease pressure, converse efficiently and sympathize with others, conquer challenges and disperse conflict.

In 1990, Salovey and Mayer described the domain as the "tendency to check one's own and others' approach and emotions to distinguish between them and to employ this knowledge to direct one's thoughts and events." Emotional intelligence is defined as a bunch of interconnected skill regarding the tendency of people to perceive exactly, assess and articulate emotions; the tendency to access and exhibit feelings when they ease thought; the capability to know emotion and emotional information and the capability to control emotions to encourage emotional and scholarly growth (Suan and Nasurdin, 2011).

Emotional Intelligence stands for the tendency to distinguish, manage, and appraise emotions. Few authors advocate that emotional intelligence may be educated and reinforced, while other declares it is a natural trait. As a conclusion many models and procedures have been constructed, providing the psychological field unconventional customs to formalize and evaluate the domain. Rationale for the variety in models of emotional intelligence can be credited to the collection of psychological variables they have determined to incorporate; specifically from conventional personality attributes including assertiveness and flexibility to mental abilities that unite expertise from several emotional intelligence vicinity (Herman, 2012).

Emotional intelligence can be build by dropping strain, lingering resolute, and staying connected with other persons. People can do this by learning main skills.

\section{SOCIAL ADJUSTMENT}

Haloren and Santrock (1997) describe adjustment as "the psychological process of adapting to new environment, handling their problem and coping with needs of daily life". If student have positive adjustment, they can face the difficulties of life and can beat for achieving their goals (Wolfok, 2001), in opposite to -ve adjustment in which it leads to irritation (Ishak et al., 2011).

Social adjustment is an effort made by an individual to cope with standards, values and needs of a society in order to be accepted. Social adjustment means those types of relationship which involves the accommodation of the individual to circumstances in his environment for the satisfaction of his needs or motives.

\section{SIGNIFICANCE}

Most secondary School students are adolescents. They have some social, values and emotional changes at this level. Change in the emotions is the main problem which they have to face at this stage. They have to adjust in different environment. A major hurdle during this period is managing emotions and developing interpersonal relationship.

According to Mayer et al., (2008) research on emotional intelligence training programs and its consequences are still at the juvenile stage in the realm of emotional intelligence. 
This study contributed to the present body of research on emotional intelligence training programs in the course of the understanding of the dynamics and its relevance towards social adjustment of students.

Emotionally intelligent students who are pleased with their schools frequently impact significant and quantifiable student accomplishment. These students produce and preserve surroundings where teachers and students experience appreciated. Emotionally intelligent students are conscious of and are progressively more flourishing at organizing their emotions and the emotions of others around them. Thus, this study is significant in the way that it possibly will present further ways to recognize the impact of emotional intelligence training program on social adjustment of secondary school students.

\section{OBJECTIVES}

1) To develop the emotional intelligence training program for secondary school students.

2) To see the impact of emotional intelligence training program on social adjustment of these students.

\section{Hypothesis}

1) There exists significant impact of emotional intelligence training program on social adjustment of students.

\section{RESEARCH METHOD}

The experimental method is a systematic and scientific approach to research in which the researcher manipulates one or more variables, and controls and measures any change in other variables. Population in the present investigation comprised of secondary school students of $9^{\text {th }}$ class affiliated to CBSE board of Kapurthala district of Punjab. The purposive sampling technique has been used to select sample for the study. A sample of $9^{\text {th }}$ class students including girls and boys were selected from class IX of Cambridge International School, affiliated to CBSE board.

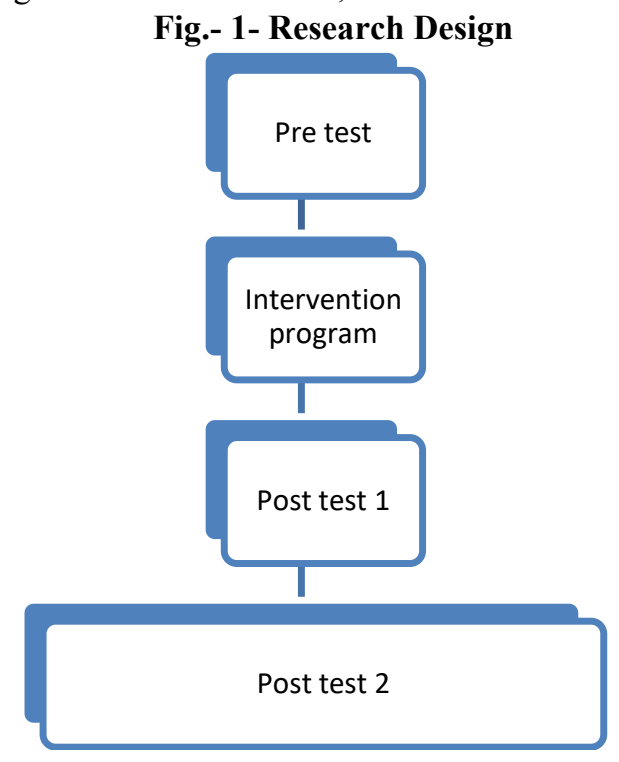

\section{TOOLS USED}

In order to collect data following tool was used in the study:

1) Social adjustment inventory by Dr. R.C. Deva (2011): The present inventory includes items for the assessment for emotional adjustment as well as social maturity. It has 100 questions. It has three scales such as emotional adjustment scale (EAS), social maturity scale (SMS), and test dishonesty scale (TDS). The reliability and validity of social adjustment inventory: the test-retest reliability of the tool is 0.91 .

2) Emotional Intelligence Training Programme developed by researcher: To conduct the study, researcher has developed the Emotional Intelligence Training Program for the secondary school students. The theoretical framework of this program is based on EI theory propounded by Daniel Goleman (1970).

This Training Program was developed in following phases

1) The researcher reviewed the literature to develop the emotional intelligence training program.

2) Various books and websites as well as professionals in the field were consulted to develop the program. All activities identified/selected were related to five components of Emotional Intelligence i.e. selfawareness, managing emotions, empathy, handling relationship and motivating one.

3) After the identification, the prime task was to convert these activities in form of modules so that these can be conducted in the class room settings. A total of 12 modules were prepared, each comprised of orientation about the one component of emotional intelligence as well as one follow-up activity to practice/develop that specific trait or the component of emotional intelligence. The content (stories and the visual presentations) and the activities of these modules were tuned per the level of secondary students of India.

The structure of the modules was as follows:

\begin{tabular}{|l|l|l|}
\hline S.NO & Total Modules & Component of EI \\
\hline 1 & 4 & Self awareness \\
\hline 2 & 3 & Managing emotions \\
\hline 3 & 2 & Motivating oneself \\
\hline 4 & 2 & $\begin{array}{l}\text { Handling } \\
\text { relationship }\end{array}$ \\
\hline 5 & 1 & Empathy \\
\hline
\end{tabular}

4) After preparation of the modules, each module had been divided into the two sub modules comprising of theoretical display of the trait in first sub module followed by practice in form of class room activities in the second sub module. Thus 12 modules had been converted into $24 \mathrm{sub}$ module, having each sub module of 30-40 minutes duration.

5) These sub modules were administered in the class room by arranging in such order so activities can be conducted after theoretical display of the individual component of the EI. 


\section{Description of the Modules}

\section{Module 1-4:-}

Module 1 to 4 had been developed to provide training on the first component of EI i.e. self-awareness. These 4 modules were divided into 8 submodules as per the following description:

\section{Sub module 1-4:}

The objective of these sub modules was to make student understand self-awareness and how to appropriately express one's self through leisure, through identification of personal characteristics, preference, interest, feelings and beliefs. Related videos and stories were included prior to the activities so that students could understand how to express one's self through leisure.

\section{Sub Module 5-8:-}

In these sub modules activities were developed for the students pertaining to their self-awareness on the basis of brainstorming. Self-awareness was bifurcated into different components including my feelings, my interest, my hobbies, things i like, my favourite possessions, my beliefs, values i share with someone else, my special traits, people who are important to me, my goals and others ideas about.

Further for self-expression, the students were given a basket of activities such as acting, cooking, crafting, dancing, drawing, gardening, jumping rope, making things, painting etc. Students were told that these activities could be creative and they responded in a dramatic manner. As a result, they felt some change about the fact that how to develop the self-expression and leisure.

Some more activities related with introduction of emotions where students were given many options on the basis of this activity such as afraid, angry, ashamed, confident, confused, depressed etc. The students were asked that how you feel when you are afraid, angry etc and they replied in a very systematic way and as a result they were in a state of transition from less self aware to self aware.

To increase the self awareness of the students, the students were also given a list of definitions that start with the letter " $h$ " in order to develop their level of self awareness. The students were told to guess and the students were very eager to answer the questions in a very kind and polite way.

\section{Module 9:-}

The objective of this module was to increase awareness of emotions. To achieve this objective student were told to read the story followed by videos. The story and video paved the way to the students so that understand what activity is all about and ultimately activity helped them in increasing their awareness of emotions.

\section{Module 10:-}

The objective of this module was to increase awareness of emotions. The name of the activity was emotions secret code activity, They were given activities like they were asked to write the letter for each number for example "Feeling upset with person, act or idea" and they were given certain numbers and on the basis of these numbers they had to answer.

\section{Module 11:-}

The objective of this module was to increase awareness of emotions. Students read a story based on awareness of emotions and a related video was also shown to them prior to the activity so that they can properly understand what activity they need to participate. They were thoroughly involved in the activity in order to develop the awareness of emotions.

\section{Module 12:-}

The objective of this module was to increase awareness of emotions. The activity was named as emotions matching activities; the activities were in the form of fill in the blanks in order to match their activities on the basis of their emotions.

\section{Module 13:-}

The objective of this module was to increase awareness of emotions. The students were not directly told to participate in the activity related to awareness of emotions but they were demonstrated in the form of story and a video shown to them. The activity helped in better shaping their emotions.

\section{Module 14:-}

The objective of this module was to understand how humor promotes a positive and happy mood. The activity was named as emotions and humor, The activities that were given to the students such as what is the best joke you have ever heard, list several funny movies and list funny cartoons and students were very cooperative and interesting in doing these kind of activities so that they could be emotionally stable and they can swing their moods also.

\section{Module 15:-}

The objective of this module was to increase the motivation of the students. The students were asked to read the story and a video was also shown to them in order to train them well for the activities. The story and the video were solely based on motivation and which helped the students in increasing their motivation.

\section{Module 16:-}

The objective of this module was to increase the motivation of the students. The name of the activity was making menu, the activities assigned to the students were based on making a menu which includes certain tasks like students were asked the questions like foods that begins with "b". The students were very enthusiastic and willing to involve themselves into the activities and thereby gained the internal motivation also.

\section{Module 17:-}

The objective of this module was to increase the motivation of the students. The story and video was purely based on the motivation and then activities were given to them in order to enhance their level of motivation. 


\section{Module 18:-}

The objective of this module was to increase the motivation of the students. The activity has been named as arctic facts, the activities were based on arctic facts and students were given a passage and they were told to read the passage and on the basis of that they were asked to answer certain questions such as people, location, animals and climate and the students find it very interesting and they were also internally motivated as well.

\section{Module 19:-}

The objective of this module was to develop understanding of the relationship skills, specifically through managing interpersonal conflict and seeking help when needed. Story and video was introduced to the students so may have prior understating of what activities they will do. The activities helped the students to develop understanding of the relationship skills, specifically through managing interpersonal conflict and seeking help when needed.

\section{Module 20:-}

The objective of this module was to develop understanding of the relationship skills, specifically through managing interpersonal conflict and seeking help when needed. The activity was labelled as instructions for facilitators for activities on managing interpersonal conflict hands-on activities. The students were given two activities like anger ball toss and feelings check in and the students responded in a very enthusiastic manner and were very good in handling the relationship during the activities.

\section{Module 21:-}

The objective of this module was to develop understanding of the relationship skills, specifically through managing interpersonal conflict and seeking help when needed. The students were told to read the story followed by a video so that they don't face any problem in doing the activities about understanding of the relationship skills, specifically through managing interpersonal conflict and seeking help when needed. The activities assisted the students in better understanding the relationship skills and seeking help when needed.

\section{Module 22:-}

The objective of this module was to develop understanding of the relationship skills, specifically through managing interpersonal conflict and seeking help when needed. The activity was done in the group to develop the relationship among the students.

\section{Module 23:-}

The objective of this module was to be aware of other's emotions. The objective was achieved by involving the students in activities but prior to that student were told to read a story and a video related to that. The activities helped the students to make them familiar with others emotions.

\section{Module 24:-}

The objective of this module was to be aware of other's emotions. The activity has been labelled as expressing empathy; students were involved in these activities on the idea of learning by doing in order to prepare them for expressing empathy. The students were given certain situations like Danny slipped on ice, fell, and broke his arm. How might he feel? And they had to answer this question so that they can show some part of empathy. The students felt very positive being involved in this activity and promised that they will be good in expressing empathy.

\section{Establishment of Validity}

Validity of the program can be divided in following parts: The face validity was established with the help of different experts in the field by taking their feedback. Convergent validity is the extent to which the item of the construct such as emotional intelligence is measuring the construct. The activities of emotional intelligence were taken into consideration so that these activities can measure or converge emotional intelligence of students. The idea of inclusion of activities pertaining to emotional intelligence was based on the book 'Exploring through Activities' authored by Pettry in 2006. The ideas of the contents of the intervention program (videos, stories and activities) has been taken from the website (www.DannyPretty.com) in order to increase the emotional intelligence and were shown to the experts for their opinions and similarly some of the stories were modified and some were deleted and some were retained. Similarly, activities and videos were also shown to experts prior to Experiments and were modified accordingly.

\section{Administration of the program}

1) The intervention programs have been conducted on 21 students of $9^{\text {th }}$ grade of Cambridge International School, Phagwara, the program was based on 24 modules with duration of 12 hours.

2) The pre-test of the social adjustment has been taken into consideration by administering the questionnaire to the respondents.

3) Consequently, post-test has been conducted with the same respondents (students from Cambridge International School).

4) Another post-test has been conducted after three weeks of the first post-test.

\section{STATISTICAL TECHNIQUES}

To study the difference between pretest, posttest 1 and posttest 2, analysis of variance was used.

\section{1) Description of pre test, post test 1 and post test 2}

Description of statistics for pre, post test 1 and post test 2 is given in following table:

Table-1 Summary Table for Mean and SD

\begin{tabular}{|c|c|c|c|c|}
\hline Sr.N. & Tests & $\mathbf{N}$ & Mean & SD \\
\hline 1 & PRE-TEST & 21 & 78.57 & 35.65 \\
\hline 2 & $\begin{array}{l}\text { POST- } \\
\text { TEST1 }\end{array}$ & 21 & 94.24 & 30.81 \\
\hline 3 & $\begin{array}{l}\text { POST- } \\
\text { TEST2 }\end{array}$ & 21 & 114.38 & 33.88 \\
\hline
\end{tabular}


In the above table the researcher administered Pre-test, Post-test 1 and Post-test 2 on 21 students of $9^{\text {th }}$ class. The mean score of the pre-test, post-test 1 and post-test 2 is 78.57 , 94.24 and 114.38 respectively. Standard deviation of the pre-test, post-test 1 and post-test 2 is $35.65,30.81$ and 33.88 respectively.

\section{2) Diffrence Between Pre- Test And Post-Test 1}

Table - 2 Difference between pre-test and post- test1 : Summary Table Analysis of Variance

\begin{tabular}{|l|l|l|l|}
\hline SOV & SS & DF & MS \\
\hline $\begin{array}{l}\text { Between } \\
\text { Groups }\end{array}$ & 2577.17 & 1 & 2577.17 \\
\hline $\begin{array}{l}\text { Within } \\
\text { Groups }\end{array}$ & 37365.62 & 20 & 1860.28 \\
\hline $\begin{array}{l}\text { Interaction } \\
\text { effect }\end{array}$ & 7037.33 & 20 & 351.87 \\
\hline Total & 46980.12 & 41 & \\
\hline
\end{tabular}

Table- 3 Required F-table

\begin{tabular}{|c|c|c|}
\hline F-Value & Measures & Table \\
value at
\end{tabular}

The calculated value of $\mathrm{F}$ for tests is 7.32 which is greater than the 4.35 we find in table $F$ for the .05 level of significance when $\mathrm{df} 1=1$ and $\mathrm{df} 2=20$. This means that hypothesis with respect to tests must be accepted. There exists significant impact of the emotional intelligence training program on the social adjustment of secondary school students. The mean value of the pre- test and posttest 1 also shows the impact of emotional intelligence training program on the social adjustment of secondary school students. In table 3.1 the mean of pre- test is 78.57 and the mean value of post- test 1 is 94.24 , which is greater than the pre- test.

3) Diffrence In The Post- Test1 And Post- Test2

Table - 4 Summary Table Analysis of Variance

\begin{tabular}{|l|l|l|l|}
\hline SOV & SS & DF & MS \\
\hline $\begin{array}{l}\text { Between } \\
\text { Groups }\end{array}$ & 1927.45 & 1 & 4260.22 \\
\hline $\begin{array}{l}\text { Within } \\
\text { Groups }\end{array}$ & 35477.02 & 20 & 1773.85 \\
\hline $\begin{array}{l}\text { Interaction } \\
\text { effect }\end{array}$ & 9025.34 & 20 & 451.27 \\
\hline Total & 46429.81 & 41 & \\
\hline
\end{tabular}

Table-5 : Required F-table

\begin{tabular}{|c|c|c|}
\hline F-Value & Measures & $\begin{array}{c}\text { Table value at } \\
\mathbf{0 . 0 5} \text { level }\end{array}$ \\
\hline For tests & 9.44 & 4.35 \\
\hline
\end{tabular}

The calculated value of $\mathrm{F}$ for tests is 9.44 which is greater than the 4.35 we find in table $F$ for the .05 level of significance when $\mathrm{df} 1=1$ and $\mathrm{df} 2=20$. This means that hypothesis with respect to tests must be accepted. There exists significant impact of the emotional intelligence training program on the social adjustment of secondary school students. The mean value of the post- test 1 and posttest2 also shows the impact of emotional intelligence training program on the social adjustment of secondary school students. In table 3.1 the mean of post- test 1 is 94.24 and the mean value of post- test 2 is 114.38 , which is greater than the post- test1. It is concluded from this interpretation that there exists impact of training program even after three weeks of the training given to the students.

There are several studies which supported findings of the study. Researcher mentioned some studies related to emotional intelligence and social adjustment of the students. Adeyemo (2005) in his study showed that there was a significant relationship between emotional intelligence and adjustment. Nelson and Law (2003), there are optimistic connection between scholar adjustment and emotional intelligence. Malek et al., (2011) the results of the study indicate significant mean differences between the two groups having emotional intelligence as a variable. These are the researcher who has studied the significant relationship of emotional intelligence and social adjustment. Reza and Zahra (2015), indicated that emotional intelligence training positively effects social adjustment of secondary school students. These studies show the relationship among the emotional intelligence and the social adjustment of the students. Cheshmehnuoshi (2010) results have indicated that training improves the emotional intelligence which ultimately leads people towards success in social adjustment.

\section{CONCLUSIONS}

The present investigations have its implications for teachers, students, parents, educational administrators and curriculum framer. The study enlists the following recommendations:

1) The policy makers such as CBSE and NCERT should conduct the workshops based on the emotional intelligence so that students could be able to develop and manage their emotions effectively.

2) CBSE and NCERT need to conduct the training programs completely based on emotional intelligence.

3) Curriculum planners should plan and design the curriculum in such a way so that teachers can add the elements of emotional intelligence in their teaching process.

4) Principals should take the initiate to invite the different experts of emotional intelligence and there should be proper arrangement of guest lectures for the students as well as for the teachers.

5) Teachers should provide Special training program of Emotional Intelligence for students to develop the emotions of the students. Training programs should be according to the needs and requirements of the students, so 
that students can understand the concept easily.

6) Parents should accept the emotions of the child, rather than denying or minimizing them. Parents should teach their child to feel the emotions without needing to act them.

7) The findings of the research have practical and theoretical implications for both researchers as well as academicians. The findings may be fruitful in terms of predicting social adjustment difficulties, thereby indicating that how students reporting such problems can be better supported and more commonly suggesting that how the transition to emotional intelligence.

\section{REFERENCES}

1 Adeyemo, D, A. and Ogunyemi, B. (2003). Emotional Intelligence and Self Efficacy as Predictors of Occupational Stress among Academic Staff in a Nigerian University.

2 Bates, P.J. (1998). Multimedia in Education. The Transition from Primary to Secondary School. Retrieved from http://www.pjb.co.uk/mmeduc.htm on 20th November 2011

3 Bhopatkar, N. (2013). Effect of Emotional Intelligence and Job Tenure on Employee Effectiveness. MERC Global's International Journal of Management, 1(2), 86102

4 Brouzos, A., Misailidi, P., \& Hadjimattheou, A. (2014). Associations Between Emotional Intelligence, SocioEmotional Adjustment, and Academic Achievement in Childhood The Influence of Age. Canadian Journal of School Psychology, 29(2), 83-99.

5 Carmeli, A. (2003). The Relationship between Emotional Intelligence and Work Attitudes, Behavior and Outcomes: An Examination among Senior Managers. Journal of Managerial Psychology, 18(8), 788-813.

6 Carnegie Council on Adolescent Development Carnegie Corporation of New York (1995). Great Transitions: Preparing Adolescents for a new century.Carnegie council on Adolescent Development. New York: Carnegie Corporation of New York.

7 Cheshmehnuoshi, M. (2010). Efficacy of training components of emotional intelligence on social adjustment and social intimacy. Master Thesis, University of Tehran, Iran

8 Clarke, N. 2006a. Developing emotional intelligence through workplace learning: Findings from a case

9 Closson, Rosemary B.; Henry, Wilma J (2008). The Social Adjustment of Undergraduate White Students in the Minority on an Historically Black College Campus. Journal of College Student Development 40 (6) p 517 534.

10 Crockett, L. J., Shanahan, M. J., \& Jackson-Newsom, J. (2005). Rural Youth: Ecological and Life Course Perspectives. $\quad$ Retrieved from http://digitalcommons.unl.edu/psychfacpub/246 on 13 November, 2014

11 Delisle, D., \& Delisle, J. (2007). Growing Good Kids: 28 Activities to Enhance Self-awareness, Compassion, and Leadership. Free Spirit Publishing.

12 Drago, J.M. (2004). Relationship between Emotional traditional College Students. Consutium report for research on emotional intelligence in organisation, U.S.A.

13 Duru, E. (2008). The Predictive Analysis of Adjustment Difficulties from Loneliness, Social Support, and Social Connectedness. Educational Sciences: Theory and Practice, 8(3), 849-856. Intelligence and Academic Achievement of Non-

14 Elias, M. J., \& Weissberg, R. P. (2000). Primary Prevention: Educational Approaches to Enhance Social and Emotional Learning. Journal of School Health, 70 (5), 186-190

15 Farmer, T., Irvin, M., Thompson, J., Hutchins, B., \& Leung, M. (2006). School Adjustment and the Academic Success of Rural African American Early Adolescents in the Deep South. Journal of Research in Early Education, 21, 1-14.

16 Freedman, J. M., McCown, K, S., Jensen, A. L. and Rideout, M. C. (1998). Self science: The emotional intelligence curriculum.

17 Ghabanchi, Z. (2014). The Correlation of IQ and Emotional Intelligence with Reading Comprehension. Reading Matrix, 14.

18 Gliebe, S. K. (2012). Strategies to Foster Emotional Intelligence in Christian Higher Education. Christian Higher Education, 11(4), 253-259.

19 Goleman, D. (1995). Emotional Intelligence: Why it can Matter More Than IQ? New York: Bantam Books.

20 Goleman, D. (1997) Emotional Intelligence, Bantam Books, Inc.

21 Goleman, D., Boyatzis, R., \& McKee, A. (2004). Primal leadership. Boston: Harvard Business School Press.

22 Hansenne, M., \& Legrand, J. (2012). Creativity, emotional intelligence, and school performance in children. International Journal of Educational Research,53, 264-268.

23 Herman, C. (2012). Developing Emotional Intelligence for Increased Work Engagement, Organizational Commitment and Satisfaction with Work Life.Doctoral dissertation, University of Stellenbosch.

24 Houtmeyers, K. A. (2000). Attachment Relationship and Emotional Intelligence in Preschoolers. Doctoral Dissertation, University of Windsor,Canada

25 Ishak, N. A., Jdaitawi, M., Ibrahim, Y. S., \& Mustafa, F. (2011). Moderating Effect of Gender and Age on the Relationship between Emotional Intelligence with Social and Academic Adjustment among First Year University Students. International Journal of Psychological Studies, 3(1), 78-89.

26 Jimenez-Morales, M. I., \& Lopez-Zafra, E. (2013). The impact of students'perceived emotional intelligence, social attitudes and teacher expectations on academic performance. Electronic Journal of Research in Educational Psychology, 11(1), 75-98.

27 Kaelber, K. A. Y., \& Schwartz, R. C. (2014). Empathy and Emotional Intelligence among Eastern and Western Counsellor Trainees: A Preliminary Study. International Journal for the Advancement of Counselling, 36(3), 274286.

28 Karami Nejad, R., \& Moradpoor, Z. (2015). The Impact of Emotional Intelligence Training on Aggressive Students' Social Adjustment. J. Appl.Environ. Biol. Sci,5(5S), 291-296

29 Kazi, S. S., Shah, I. M. and Khan, A. (2013). Occupational Stress, Performance and Emotional Intelligence: A Critical Review, International Review of Social Sciences, 5(1), 185-191,66

30 Kiyani, K., Saher, N., Saleem, S., \& Iqbal, M. (2013). Emotional Intelligence (EI) and Employee Outcomes: The Mediating Effect of Authentic Leadership Style, Interdisciplinary Journal of Contemporary Research in Business, 5(1), 394-405 
31 Kobe, L. M., Reiter-Palmon, R. and Rickers, J. D. (2001) Self-reported leadership experiences in relation to inventoried social and emotional intelligence, Current Psychology: Developmental, Learning, Personality,Social, 20 (2): 154-163.

32 Labby, S., Lunenburg, F. C., \& Slate, J. R. (2012). Emotional Intelligence and Academic Success: A Conceptual Analysis for Educational Leaders. Preparation, 7(1), n1.

33 Lawrence, A. S. Arul; Deepa, T.(2013) Emotional Intelligence and Academic Achievement of High School Students in Kanyakumari District. Retrieved from http://www.academia.edu/2590707/emotional_intelligenc e_and_academic_achievement_of_high_school_students in_kanyakumari_district on 24 november, 2014

34 Lawrence, A. S., \& Deepa, T. (2013). Emotional Intelligence and Academic Achievement of High School Students in Kanyakumari District. Online Submission, 3(2), 101-107.

35 Luthar, S. S., Cicchetti, D., \& Becker, B. (2000). The Construct of Resilience: A Critical Evaluation and Guidelines for Future Work. Child development, 71, 543562.

36 Malek, J. T., Noor-Azniza, I., Muntasir, T. A., Mohammad, G. N. and Luqman, R. M. (2011). The Effectiveness of Emotional Intelligence Training Program on Social and Academic Adjustment among First Year University Students. International Journal of Business and Social Sciences, 2(24), 251-258

37 Mayer, J. \& Cobb, C. (2000). Educational Policy on Emotional Intelligence: Does it Make Sense? Educational Psychology Review, 12, 2, 163-183.

38 Mayer, J. D. and Geher, G. (1996) Emotional intelligence and the identification of emotion, Intelligence, 22 (2): 89114.

39 Mayer, J. D., Roberts, R. D., and Barsade, S. G. (2008). Human Abilities: Emotional Intelligence. Annual Review of Psychology, 59, 507-536.

40 Mayer, J., Salovey, R, \& Caruso, D. (2000).Competing Models of Emotional Intelligence. Retrieved from http://www.unh.edu/emotional_intelligence/EI\%20Assets /Reprints...EI\%20Proper/EI2000ModelsSternberg.pdf on 22 November, 2014

41 Mayer, J.D., Dipaolo, M. \& Salovey, P. (1990). Perceiving Affective Content in Ambiguous Visual Stimulating Emotional Intelligence. Journal of Personality Assessment, 54, 772-781.

42 Mcgee, C., Ward, R., Gibbon, J. \& Harlow, A. (2003). Transition to Middle School: A Literature Review. Retrieved from www.minedu.govt.nz on $14^{\text {th }}$ November, 2014

43 Moore, Amanda; Mamiseishvili, Ketevan, Examining the Relationship between Emotional Intelligence and Group Cohesion. Journal of Education for Business, 87(5), 296302 retrieved from $h t t p: / / w w w . t a n d f . c o . u k / j o u r n a l s$

44 Oginska-Bulik, N. (2005). Emotional Intelligence in the Workplace: Exploring its Effects on Occupational Stress and Health Outcomes and Health Outcomes in Human Service Workers. International Journal of Occupational Medicine and Environmental Health, 18(2), 167-175

45 Pettry, D. W. (2006). Exploring Emotions through Activities. Retrieved from http://www.dannypettry.com/ebook_emotions.pdf. on 15 November, 2014

46 Poulou, Maria S. (2014). How Are Trait Emotional Intelligence and Social Skills Related to Emotional and Behavioural Difficulties in Adolescents? Educational Psychology: An International Journal of Experimental Educational Psychology, 34(3). International journal of Educational Leadership

47 Pour, K. M., Adibsereshki, N., PourmohamadrezaTajrishi, M., \& Hosseinzadeh, S. (2014). The Effect of Emotional Intelligence Training on Behaviour Problems of Boys with Externalized Behaviour Disorder in Elementary Schools. Journal of Special Education and Rehabilitation, 15(3-4), 59-76.

48 Rausch, J. L., \& Hamilton, M. W. (2006). Goals and Distractions: Explanations of Early Attrition from Traditional University Freshmen. The Qualitative Report, 11, 317-334.

49 Ravichandran, K., Arasu, R. and Kumar, S. A. (2011). The Impact of Emotional Intelligence on Employee Work Engagement Behavior: An Empirical Study. International Journal of Business Management, 6(11), 157-169

50 Rosakis, L. (1981). fresh \& fun critical-thinking activities: Engaging activities and reproducibles to develop kids' higher-level thinking skills.

51 Salovey, P. and Mayer, J. D. (1990) Emotional intelligence, Imagination, Cognition \& Personality, 9 (3): 185-211.

52 Salovey, P. and Pizarro, D. (2003) Chapter 16: The value of emotional intelligence, In R. J. Sternberg, J. Lautrey and T. I. Lubart (Eds.), Models of intelligence: international perspectives: 263-278. Washington, DC: American Psychological Association.

53 San Mateo: Six Seconds. Sullivan, A. K. (1999). The Emotional Intelligence.

54 Sangwan, S. P. S. (2011). Emotional Intelligence and Social Adaptation of School Children. Journal of Psychology, 2(2), 83-87

55 Schuttle, N.S., MArlouf, J.M.; Hall, I.E., Haggerty, D.J., Copper, J.T. \& Donheim (1998). Development and Validation of a Measure of Emotional Intelligence. Personality and Individual Difference 25, 167-177.

56 Sevinc, S., \& Gizir, C. A. (2014). Factors Negatively Affecting University Adjustment from the Views of First-Year University Students: The Case of Mersin University. Educational Sciences: Theory \& Practice, 14(4), 1301-1308.

57 Stubbs, E. C. (2005). Emotional Intelligence Competencies in the Team and Team Leader: A MultiLevel Examination of the Impact of Emotional Intelligence on Group Performance study in healthcare. Human Resource Development International 9(4), 447465.

58 Suan, C. L. and Nasrudin, A. M. (2011). The Effects of Emotional Intelligence and Gender on Work Engagement of Customer-Contact Employees: A Proposed Framework. Research Journal of Business Management, 5(4), 178-186

59 Suffolk Education Department, Inspection and Advice Division (1997). A Report into the Investigation into What Happens When Pupils Transfer into Their Next Schools at The Ages of 9, 11 And 13 .

60 Thor, S. and Johnson, C. (NA). Leadership, Emotional Intelligence and Work Engagement: A Literature Review, Retrieved from http://www.scottthor.com/wpcontent/uploads/2013/05/Leadership-EmotionalIntelligence-and-Work-Engagement-Scott-Thor-andCraig-Johnson.pdf on 19th November, 2014

61 Tohid, M. S,. Kamran, J., \& Rajeshwari, K. (2014) Emotional Intelligence and Social Responsibility of Boy Students in Middle School. Conflux Journal of Education, 4(2), 30-34. 
62 Ulutaş, I., \& Omeroglu, E. (2007). The Effects of an Emotional Intelligence Education Program on the Emotional Intelligence of Children. Social Behaviour and Personality: An International Journal, 35(10), 13651372.

63 Veitch, B. L., \& Justice, M. (2011). Developmental Education and Emotional Intelligence in Three Rural East Texas Community Colleges

64 Ward, R. (2000). Transfer from Middle to Secondary School: A New Zealand Study. International Journal of Educational Research, 33, 365-374.

65 Wilson, S. L. (2009). The Effects of the Emotional Intelligence of Elementary School Principals on Student Outcomes. ProQuest LLC. 789 East Eisenhower Parkway, PO Box 1346, Ann Arbor, MI 48106.

66 Wong, C.-S. and Law, K. S. (2002).The effects of leader and follower emotional intelligence on performance and attitude: An exploratory study, Leadership Quarterly, 13 (3): 243-274.

67 Zia, M., Chamanzamin, M. R. and Moghimee, S. F. (2014). Investigating the Effect of Emotional Intelligence Components on Organizational Maturity and Job BurnOut in Mapna Company's Staff in Paresar Combined Cycle Power Plant. International Review of Management and Business Research, 3(3), 1767-1772 